\title{
STUDY ON THE AROMA-THERAPEUTIC EFFECTS OF TEXTILES FUNCTIONALIZED BY HERBAL EXTRACTS
}

\author{
FLOAREA PRICOP ${ }^{1}$, ALINA POPESCU $^{1}$, MARIAN RAŞCOV $^{1}$, LAURA CHIRILA $^{1}$, \\ RĂZVAN SCARLAT ${ }^{1}$, MARIA BUZDUGAN ${ }^{2}$, ANGELA CEREMPEI ${ }^{3}$, EMIL MUREŞAN $^{3}$ \\ ${ }^{1}$ The National Research \& Development Institute for Textile and Leather, 16 L. Patrascanu Str., \\ 030508,Bucharest, Romania, e-mail: certex@ns.certex.ro \\ ${ }^{2}$ Magnum SX SRL, 61 FERDINAND I Blvd., Sector 2, 02138, Bucharest, Romania \\ 3 "'Gheorghe Asachi" Technical University of Iasi, Faculty of Textiles, Leather and Industrial \\ Management, 28 Prof. Dr. Docent D. Mangeron Blvd, 700050, Iasi, Romania
}

\begin{abstract}
This study, referring to the biologically active compounds compatible with textile materials, reveals its influence on human psychophysiological activity. In the COFUND-MANUNET IIIAromaTex project, essential oils extracted from lavender, rosemary, mint, thyme were studied and selected to be used for obtaining of aroma-therapeutic effects on textiles, as well as other various effects, such as: skin hydration and anti-acne, revitalizing and reducing stress, improving of microcirculatory blood flow and cellular metabolism. In recent years, electrophysiological studies have been reported worldwide that have shown that different flavors affect spontaneous brain activities and cognitive functions that can be measured by the EEG encephalogram. The presented study contributes to the optimization of formulations which contain essential oils adapted to the conditions of technologies application for deposition and immobilization on textiles, with a particular emphasis on the desired therapeutic effect and the controlled release of essential oils. Aromatherapy application in textile industry led to a series of value-added products that give besides comfort a number of other properties (anti-acne, antimicrobial, fragrance, antiinflammatory sedation, or soothing properties). In recent years, aromatherapeutic textiles were applied in many fields such as food, cosmetics, medicine, tobacco, textiles, leather, papermaking and pharmaceutical industries. The purpose of this chapter was to present the essential oils used in textile finishing, textile supports used for aroma finishing, embedding methods and the controlled release of essential oils.
\end{abstract}

Keywords: aromatherapy, essential oils, textile materials.

\section{INTRODUCTION}

Aromatherapy is one of the complementary therapies which use essential oils as the major therapeutic agents to treat several diseases. The essential or volatile oils are extracted from the flowers, barks, stem, leaves, roots, fruits and other parts of the plant by various methods. It came into existence after the scientists deciphered the antiseptic and skin permeability properties of essential oils. Inhalation, local application and baths are the major methods used in aromatherapy that utilize these oils to penetrate the human skin surface.

Although medicinal plants have been used for centuries as remedies for human diseases, in Romania in recent years, they have reached a great interest due to their low toxicity, pharmacological activities and economic viability. It shows a more pronounced shift from chemical and nonsustainable products to natural products that are not harmful, biodegradable and with health and wellness benefits (West and AnnettHitchcock, 2014; Boulekbache-Makhlouf et al., 2016).

Natural additives from plants can be compounds, groups of compounds, or essential oils (Boulekbache-Makhlouf et al., 2016). Among natural additives, essential oils present a particular interest due to multiple benefits it shows such as antiviral, antifungal, antibacterial, antioxidant, antiparasitic, insecticidal, radical-scavenging properties, anti-inflammatory, antiseptic, germicide, healing and emollient effects. 
Essential oils are made up of complex mixtures of several hydrocarbons (alcohols, terpenes, aldehydes, esters, phenols, oxides and ketones) and are obtained by conventional or advanced methods (Figure 1) (Ghosha and Chipot, 2015; El Asbahani et al., 2015).

Essential oils are fat soluble and thus they have the ability to permeate the skin membranes and drained into the systemic circulation, which reaches all targets organs (Radulovic et al., 2011; Kandori, 2002). Essential oils are considered "vital force" of the plants.
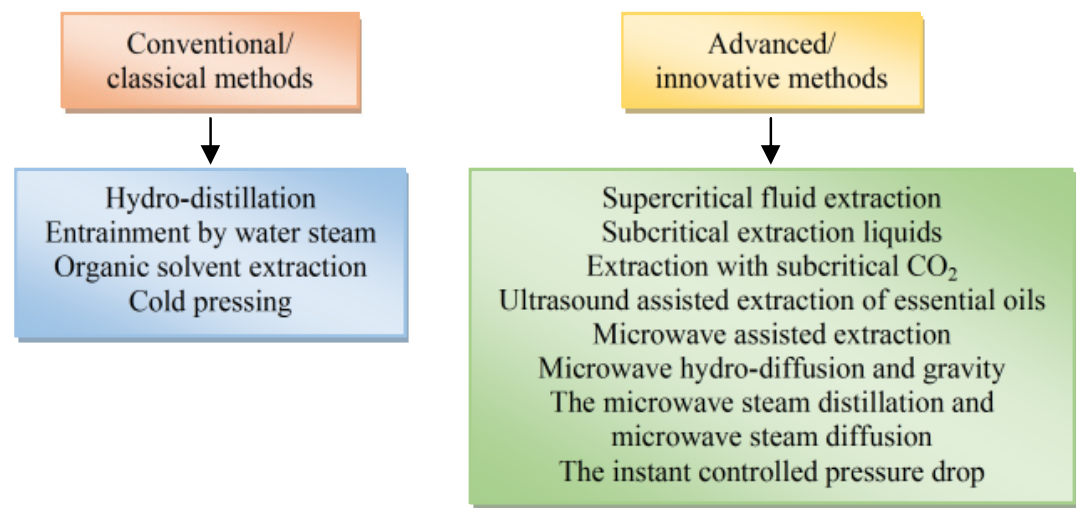

Figure 1. Extraction methods of essential oils (Cerempei 2017)

The role of these oils in plants is similar to that of the blood in the body. Fat-soluble structure of essential oils is similar to that of cells and tissues in the human body. This makes them compatible with human proteins and allows them to be easily identified and accepted by the body. Due to the fat-soluble structure and very small-size molecules, essential oils serve as transport agents that easily penetrates the cell membrane. Only one application of essential oils is sufficient to stimulate and revitalize the entire body. Recent research has shown that essential oils are able to penetrate the barrier $\mathrm{blood} / \mathrm{brain}$ due to their small size $(\leq 500 \mathrm{amu})$ (Balabai, 1988).

\section{CHEMICAL COMPOSITION OF THE MAIN ESSENTIAL OILS USED IN RESEARCH}

Essential oils represent less than 5\% from vegetal dry matter and are complex mixtures of volatile compounds extracted from plants (Abraham et al., 2013; Rachwalik et al., 2012).

Chemical composition of the main essential oils used in textile industry, identified by gas chromatography (GC) and GC-mass spectrometry (GC-MS), is presented in Table 1 (Duhamela et al., 2016; Skalicka-Woz'niak and Walasek, 2014; Timung et al., 2016; Jamali et al., 2013; González-Rivera, 2016; Kumar et al., 2010). 
ICAMS $2018-7^{\text {th }}$ International Conference on Advanced Materials and Systems

Table 1. The chemical composition of the main essential oils to be used in the project

\begin{tabular}{|c|c|c|c|c|}
\hline Essential oil & Chemical type & $\begin{array}{l}\text { Main compounds } \\
\text { Composition }\end{array}$ & Composition (\%) & References \\
\hline \multirow{6}{*}{ Peppermint } & \multirow{6}{*}{$\begin{array}{l}\text { Oxygenated } \\
\text { compounds }\end{array}$} & Menthol & 36 & \multirow[t]{6}{*}{$10,11,12$} \\
\hline & & Menthone & 21,24 & \\
\hline & & Menthyl acetate & 6.92 & \\
\hline & & Eucalyptol & 6.58 & \\
\hline & & Isomenthone & 4.71 & \\
\hline & & Neomenthol & 4.06 & \\
\hline \multirow[t]{4}{*}{ Lavender } & \multirow{4}{*}{$\begin{array}{l}\text { Monoterpenes } \\
\text { Oxygenated } \\
\text { monoterpenes }\end{array}$} & $\alpha$-Pinene & $3.4 \%$ & \multirow[t]{4}{*}{15} \\
\hline & & 1,8-cineole & $33.0 \%$ & \\
\hline & & Camphor & $23.1 \%$ & \\
\hline & & $\alpha$-Bisabolool & $14.1 \%$ & \\
\hline \multirow{2}{*}{$\begin{array}{l}\text { Rosemary } \\
0 \\
0\end{array}$} & Monoterpene & $\beta$-Pinene & $4.1 \%$ & \multirow[b]{2}{*}{15} \\
\hline & Bicyclic & $\alpha$-Pinene & $28.2 \%$ & \\
\hline \multirow{6}{*}{ 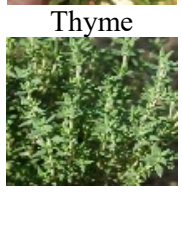 } & \multirow{3}{*}{$\begin{array}{l}\text { Oxygenated } \\
\text { compounds }\end{array}$} & Oxygenated & $14.1-77.6$ & \multirow{6}{*}{13,14} \\
\hline & & compounds & $0.5-27.8$ & \\
\hline & & Thymol & $0.2-16.3$ & \\
\hline & \multirow[t]{3}{*}{ Monoterpenes } & Borneol 0.2-16.3 & $3.8-6.6$ & \\
\hline & & $\gamma$-Terpinene & $3.5-7.9$ & \\
\hline & & $\begin{array}{l}\text { p-Cymene } \\
\alpha \text {-pinene }\end{array}$ & $1.2-7.8$ & \\
\hline
\end{tabular}

\section{INFLUENCE OF THE PHYSICO-CHEMICAL AND MICROBIOLOGICAL PROPERTIES OF ESSENTIAL OILS ON TREATED TEXTILES}

Antiseptic of the respiratory, analgesic, sedative and balancing of the central and vegetative nervous system (Bouchekrit et al., 2016; Leimann et al., 2009).

Indications: insomnia, neurasthenia, and in cases of palpitations of nervous origin of the heart, in general, in all cases of psychosomatic diseases. Due to its sedative effect it is recommended in migraines and other headaches.

Applied externally it is very effective to calm rheumatic pains, whether of joint or muscular origin. Useful in dislocations, sprains, contusions and muscular strains. As an antiseptic and healing agent it is used to wash ulcers and infected wounds, as well as in minor burns. Physicochemical properties and microbiological properties are presented in tables 2 and 3 (Cerempei, 2017; Zarrad et al., 2015; Al-Jabri and Hossain, 2016).

Table 2. Physicochemical properties

\begin{tabular}{ll}
\hline Relative density & $0.9400-1.0950$ \\
Density of alcohol & $0-10$ G.L. \\
Relative ph & $4.50-8.00$ \\
\hline
\end{tabular}


Table 3. Microbiological properties

\begin{tabular}{ccc}
\hline Determination & Limit $(\mathrm{UFC} / \mathrm{mL})$ & Method used \\
\hline Aerobic mesophilics & 105 & NOM-092-SSA1-1994 \\
Mushrooms and yeast & 103 & NOM-111-SSA1-1994 \\
Escherichia coli & 10 & NOM-113-SSA1-1994 \\
\hline
\end{tabular}

\section{FUNCTIONALIZATION OF TEXTILES WITH PLANT EXTRACTS AND APPLICATIONS IN MEDICINE}

Due to essential oils that can act both at local level and through odor, they have great important applications in many fields such as food, cosmetics, medicine, tobacco, textile, leather, papermaking, pharmaceutical and perfume industries (Hu et al., 2001).

Essential oils add much value to the textile materials. The most commonly used essential oil in aroma finishing is lavender essential oil due to its properties: anti-acne, antibacterial, calming, anti-inflammatory, treatment of eczema and dermatitis. The introduction of the concept of aromatherapy for textiles has brought increasing demands for consumers in terms of quality, comfort and functionality of textile products. There was a shift in their values.

Aroma finish is a process by which the textile materials are treated with bioactive systems (e.g., chitosan/essential oil, alginate/essential oil systems) and finally get the multifunctional properties such as therapeutic effects and a feeling of well-being and freshness in the wearer.

Aromatherapy textiles are used in medicine and alternative healing, home textiles, body-care textiles, household cleaning and cosmetic products.

The aromatherapy materials that first appeared on the market were socks for women who like fragrances. Hosiery and intimate apparel have been the more widely explored product categories to apply aroma finishing. In recent years, a number of companies around the world turned their attention to aromatherapy textiles. Woolmark ${ }^{\mathrm{TM}}$ is applying aroma technology to hosiery, lingerie, socks, outdoor clothing, underwear, carpeting and other interior textiles.

\section{The Benefits of Aromatherapy}

- It's fast;

- It's efficient;

- It's discreet;

- Makes long-term transformations;

- It's nice;

- It's the fastest way to raise your personal vibration;

- Helps a lot of healing processes;

- Increases the power of medication assimilation;

- Maintains a reference standard in thinking, feelings and human experiences;

- It gives great chances to special cases, prevents various aspects of bacterial and fungal diseases;

- It's a system for treating the environment in which people work;

- Creates a pathogen-damaging environment (viruses, bacteria etc.). 


\section{CONCLUSIONS}

The complex studies carried out in this new field have revealed that bioactive compounds (essential oils) have more than a therapeutic but also ecological, social effect, contributing to the increase in the value of the products and their quality.

The techniques proposed in the project are ecological, with no environmental consequences. Ecological, biodegradable and biocompatible products will be used in the project to obtain aroma therapeutic and skin/body care textile products. The environmental impact is as low as possible, contributing to life and health quality.

\section{Acknowledgment}

This work was supported by a grant of the Romanian National Authority for Scientific Research and Innovation, CCCDI - UEFISCDI, project number 29/2018 COFUND-MANUNET III-AromaTex, project title "Manufacturing of value-added textiles for aromatherapy and skin care benefits", within PNCDI III.

\section{REFERENCES}

Abraham, M.H. et al. (2013), "Determination of solvation descriptors for terpene hydrocarbons from chromatographic measurements", Journal of Chromatography A., 1293, 133-141, https://doi.org/10.1016/j.chroma.2013.03.068.

Cerempei, A. (2017), “Aromatherapeutic Textiles”, Active Ingredients from Aromatic and Medicinal Plants, Hany El-Shemy, IntechOpen, https://doi.org/10.5772/66510.

AL-Jabri, N.N. and Hossain, M.A. (2018), "Chemical composition and antimicrobial potency of locally grown lemon essential oil against selected bacterial strains”, Journal of King Saud University - Science, 30(1), 14-20, https://doi.org/10.1016/j.jksus.2016.08.008.

Balabai, I.V. (1988), Rasteniea, coterie nas leceat, I.V. Balabai, A.C. Nistrean, Chisinau, 351.

Bouchekrit, M. et al. (2016), "Essential oils from Elaeoselinum asclepium: chemical composition, antimicrobial and antioxidant properties", Asian Pacific Journal of Tropical Biomedicine, 6(10), 851-857, https://doi.org/10.1016/j.apjtb.2016. 07.014.

Boulekbache-Makhlouf, L. et al. (2016), "Essential oils composition, antibacterial and antioxidant activities of hydrodistillated extract of Eucalyptus globulus fruits Z. Bey - Ould Si Saida, H. Haddadi Guemghar", Industrial Crops and Products, 89, 167-175.

Duhamel, N. et al. (2016), "Convenient synthesis of deuterium labelled sesquiterpenes", Tetrahedron Letters, 57(40), 4496-4499.

El Asbahani, A. et al. (2015), "Essential oils: from extraction to encapsulation", International Journal of Pharmaceutics, 483, 220-243, https://doi.org/10.1016/j.ijpharm.2014.12.069.

Ghosha, S. and Chipot, N. (2015), "Embedding aromatherapy essential oils into textile fabric using $\beta$ cyclodextrin inclusion compound", Indian Journal of Fibre \& Textile Research, 40, 140-143.

González-Rivera, J. et al. (2016), "Coaxial microwave assisted hydro-distillation of essential oils from five different herbs (lavender, rosemary, sage, fennel seeds and clove buds): chemical composition and thermal analysis", Innovative Food Science \& Emerging Technologies, 33, 308-318.

$\mathrm{Hu}$, J. et al. (2001), "Properties of aroma sustained-release cotton fabric with rose fragrance nanocapsule", Chinese Journal of Chemical Engineering, 19(3), 523-528.

Jamali, C.A. et al. (2013), "Phenological changes to the chemical composition and biological activity of the essential oil from Moroccan endemic thyme (Thymus maroccanus Ball)", Industrial Crops and Products, 49, 366-372, https://doi.org/10.1016/j.indcrop.2013.05.016.

Kandori, I. (2002), "Diverse visitors with various pollinator importance and temporal change in important pollinators of Geranium thunbergii (Geraniaceae)", Ecological Research., 17, 283-294, https://doi.org/10.1046/j.1440-1703.2002.00488.x.

Kumar, A. et al. (2010), "Chemical composition, antifungal and antiaflatoxigenic activities of Ocimum sanctum L. essential oil and its safety assessment as plant based antimicrobial", Food and Chemical Toxicology, 48(2), 539-543.

Leimann, F.V. et al. (2009), "Antimicrobial activity of microencapsulated lemongrass essential oil and the effect of experimental parameters on microcapsules size and morphology", Materials Science and Engineering: C., 29(2), 430-436. 
Radulovic, N. et al. (2011), "Chemical composition and antimicrobial activity of the essential oils of Geranium columbinum L. and G. lucidum L. (Geraniaceae)”, Turkish Journal of Chemistry, 35, 499-512.

Rachwalik, R. et al. (2012), "Transformations of monoterpene hydrocarbons on ferrierite type zeolites", Applied Catalysis A: General, 427-428, 98-105, https://doi.org/10.1016/j.apcata.2012.03.037.

Skalicka-Woz'niak, K. and Walasek, M. (2014), "Preparative separation of menthol and pulegone from peppermint oil (Mentha piperita L.) by high-performance counter-current chromatography", Phytochemistry Letters, 10, XCIV-XCVIII.

Timung, R. et al. (2016), "Composition and anti-bacterial activity analysis of citronella oil obtained by hydrodistillation: process optimization study", Industrial Crops and Products, 94, 178-188.

West, A.J. and Annett-Hitchcock, K.E. (2014), "A critical review of aroma therapeutic application for textiles", Journal of Textile and Apparel, Technology and Management, 9(1), 1-13.

Zarrad, K. et al. (2015), "Chemical composition, fumigant and anti-acetylcholinesterase activity of the Tunisian Citrus aurantium L. essential oils", Industrial Crops and Products, 76, 121-127, https://doi.org/10.1016/j.indcrop.2015.06.039. 